\title{
PENGARUH PENDAPATAN ASLI DAERAH, INVESTASI PEMERINTAH DAN ANGKATAN KERJA TERHADAP PRODUK DOMESTIK REGIONAL BRUTO KABUPATEN/KOTA DI JAWA
}

\author{
Anik Ambarwati dan Payamta \\ Magister Akuntansi \\ Fakultas Ekonomi dan Bisnis - Universitas Sebelas Maret Surakarta
}

\begin{abstract}
ABSTRAK
Penelitian ini bertujuan untuk mengetahui pengaruh pendapatan asli daerah, investasi pemerintah dan angkatan kerja terhadap produk domestik regional bruto dengan aset daerah dan jumlah SKPD sebagai variabel kontrol. Penelitian ini menggunakan data sekunder dengan kabupaten/kota di Jawa. Dari 112 kabupaten/kota di Jawa yang dapat digunakan untuk sampel sebanyak 84 kabupaten/kota selama 2 tahun yaitu 2010 sampai dengan 2011. Jadi total sampel menjadi 168. Metode analisis data yaitu metode penelitian regresi linear berganda. Pendapatan asli daerah diperoleh dari laporan realisasi anggaran (LRA), investasi pemerintah dan aset daerah berasal dari Neraca-LKPD, angkatan kerja dan produk domestik regional bruto dari profil pembangunan propinsi Jawa Barat, Jawa Tengah, Jawa Timur, DI Yogyakarta dan Banten yang merupakan hasil data dari Badan Pusat Statistik (BPS). Berdasarkan uji hipotesis secara parsial (uji t) yang telah dilakukan sebelum maupun sesudah memasukkan variabel kontrol, ditemukan bahwa pendapatan asli daerah dan angkatan kerja berpengaruh signifikan terhadap produk domestik regional bruto. Aset daerah dan jumlah SKPD yang merupakan variabel kontrol juga mempengaruhi produk domestik regional bruto. Sedangkan variabel investasi pemerintah tidak berpengaruh terhadap produk domestik regional bruto.
\end{abstract}

Kata kunci: pendapatan asli daerah, investasi pemerintah, angkatan kerja, aset daerah, jumlah SKPD, produk domestik regional bruto

\section{PENDAHULUAN}

Pelaksanaan desentralisasi pada pemerintah daerah sesuai dengan UU No 32 Tahun 2004 dan UU No 33 Tahun 2004 tentang perimbangan keuangan pusat dan daerah mewajibkan pemerintah daerah kabupaten/kota menjadi motor penggerak pembangunan diwilayahnya masing-masing. Pelaksanaan kedua UU tersebut juga menimbulkan masalah tersendiri. Masalah tersebut yaitu pilihan antara menyelenggarakan pelayanan publik yang baik atau mengalokasikan dana untuk membiayai proyek guna menambah pendapatan daerah. Hal tersebut selaras dengan kalimat dalam penelitian Setyaningrum (2012) yang mengutip dari Zimmerman tentang masalah keagenan yang terjadi pada semua organisasi. Agency problem pada perusahaan terjadi antara pemegang saham sebagai principal dan manajemen sebagai agen. Pada sektor pemerintahan agency problem terjadi antara pejabat pemerintah yang terpilih dan diangkat sebagai principal dan para pemilih (masyarakat) sebagai agen. Pejabat pada pemerintahan sebagai pihak yang menyelenggarakan pelayanan publik dapat membuat keputusan serta kebijakan yang hanya mementingkan pemerintah dan penguasa atau pilihan mengambil simpati masyarakat dengan memberikan pelayanan publik yang memuaskan dan membiayai program-program untuk meningkatkan kesejahteraan rakyat.

Pemerintah daerah kabupaten/kota merupakan salah satu organisasi sektor publik yang melaksanakan akuntansi sektor publik. Menurut Mardiasmo (2009) ada beberapa 
komponen lingkungan yang mempengaruhi perbedaan akuntansi sektor publik dan akuntansi swasta. Komponen lingkungan yang mempengaruhi organisasi sektor publik salah satunya yaitu faktor ekonomi. Perhitungan pertumbuhan ekonomi menggunakan angka-angka produk domestik bruto (PDB) untuk negara dan produk domestik regional bruto (PDRB). Produk domestik regional bruto (PDRB) merupakah hubungan pemerintah daerah dan masyarakatnya dalam mengelola sumber daya yang ada untuk menciptakan lapangan kerja baru dan merangsang perkembangan kegiatan ekonomi dalam wilayah tersebut (Arsyad 1999). Bertambahnya total nilai barang dan jasa yang diproduksi diwilayah regional tertentu dalam waktu tertentu (satu tahun) dihitung sebagai Produk Domestik Regional Bruto (Haryanto 2004).

Menurut Sukirno (2004) dalam analisis makro, tingkat pertumbuhan ekonomi yang dicapai oleh suatu negara diukur dari perkembangan pendapatan nasional riil atau Produk Domestik Bruto (PDB) sedangkan untuk daerah disebut Pendapatan Domestik Regional Bruto (PDRB). Masyhuri (2010) mengemukakan agar tugas pemerintahan yang diamanatkan oleh otonomi daerah dapat dilaksanakan dengan efisien dan efektif dibutuhkan sumber keuangan untuk mengurangi ketergantungan daerah terhadap pemerintah pusat. Salah satu indikator turunnya ketergantungan daerah terhadap pemerintah pusat adalah meningkatnya kemampuan daerah dalam menggali sumber sumber pendapatan asli daerah baik secara intensifikasi maupun ekstensifikasi.

Menurut Sasana (2006), dalam era desentralisasi fiskal di mana daerah dituntut untuk bisa melakukan fungsinya secara efektif dan efisien maka harus didukung dengan sumbersumber keuangan yang memadai. Oleh karena itu, pemerintah daerah diharapkan mampu meningkatkan kapasitas fiskalnya melalui: pengembangan aktivitas ekonomi berbasis komoditi unggulan daerah, melakukan intensifikasi dan ekstensifikasi pendapatan asli daerah untuk mendorong pertumbuhan produksi barang dan jasa suatu wilayah regional.

Salah satunya penelitian dari Sugeng (2014); Suryono (2010) yang menunjukkan bahwa PAD memiliki pengaruh signifikan terhadap PDRB. Hasil penelitian Najiah (2013) juga menyebutkan bahwa PAD secara parsial berpengaruh terhadap PDRB di Kota Depok. Rustiono (2008) menyebutkan bahwa pendapatan domestik regional bruto adalah penjumlahan dari berbagai variabel, termasuk didalamnya adalah investasi. Investasi yang terjadi di daerah terdiri dari investasi pemerintah dan investasi swasta. Investasi pemerintah dilakukan guna menyediakan barang publik. Investasi menjadi salah satu kata kunci dalam setiap upaya menciptakan pertumbuhan ekonomi baru bagi perluasan penciptaan lapangan kerja, peningkatan pendapatan dan penanggulangan kemiskinan.

Selain investasi, maka tenaga kerja merupakan salah satu faktor yang mempengaruhi out put suatu daerah. Angkatan kerja yang besar akan terbentuk dari jumlah penduduk yang besar. Menurut Todaro (2000) pertumbuhan penduduk yang cepat mendorong timbulnya masalah keterbelakangan dan membuat prospek pembangunan menjadi semakin jauh. Pemerintah daerah juga memiliki kewajiban untuk mengakomodasi dan mengurangi tingkat pengangguran dengan berbagai kebijakan daerah. Suindyah (2009) yang mengutif dari Gravitiani (2006) menulis bahwa dengan adanya kesempatan kerja baru berarti adanya penciptaan pendapatan masyarakat yang akan mendorong daya beli. Penciptaan kesempatan kerja baru juga dapat mendorong perkembangan investasi dari internal daerah yang pada akhirnya akan mendorong produk domestik regional bruto dan ekonomi daerah.

Untuk memperjelas hasil penelitian dan agar tidak bias, maka peneliti menggunakan variabel kontrol. Variabel kontrol tersebut yaitu aset daerah dan jumlah SKPD. Aset merupakan sumberdaya yang penting bagi pemerintah daerah. Dengan mengelola aset daerah secara profesional maka pemerintah daerah akan mendapatkan 
sumber dana untuk pembiayaan pembangunan di daerah. SKPD adalah pelaksana fungsi eksekutif yang harus berkoordinasi agar penyelenggaraan pemerintahan berjalan dengan baik. Menurut Sukarno (2013) bagaimanapun desain kelembagaan yang dipilih oleh pemerintah daerah, persoalannya adalah terletak pada hak otonom yang dimiliki oleh masing-masing daerah untuk menetapkan berapa jumlah Satuan Kerja Perangkat Daerah (SKPD). Peraturan terkait kelembagaan di daerah misalnya PP No. 41 Tahun 2007 masih belum komprehensif mengatur secara detail aturan main yang harus diikuti oleh daerah. Dalam pasal-pasalnya memberikan ruang yang luas untuk dimanfaatkan oleh daerah membentuk kelembagaannya sesuai dengan keinginannya tanpa disertai dengan analisis kebutuhan unsur pemerintahan. Bentuk produk perundang-undangan yang tidak komprehensif, tidak sinerji dan adanya intervensi politik atau lebih dikenal kebijakan pimpinan semakin memperparah kondisi dan beban keuangan suatu daerah. Anggaran lebih banyak dihabiskan pada belanja pegawai bukan pada belanja pembangunan untuk meningkatkan perekonomian rakyat.

\section{KAJIAN TEORI}

\section{Teori Agensi Dalam Pemerintahan}

Dalam agenci teori terdapat dua pihak yang melakukan kesepakatan atau kontrak, yakni pihak yang memberikan kewenangan yang disebut principal dan pihak yang menerima kewenangan yang disebut agen (Halim dan Abdullah 2006). Dalam penelitian Setyaningrum (2009) yang mengutip dari Zimmerman (1977) mengungkapkan bahwa masalah keagenan terjadi pada semua organisasi. Pada perusahaan agency problem terjadi antara pemegang saham sebagai principal dan manajemen sebagai agen. Pada sektor pemerintahan, agency problem terjadi antara pejabat pemerintah yang terpilih dan diangkat sebagai principal dan para pemilih (masyarakat) sebagai agen. Pejabat pada pemerintahan sebagai pihak yang menyelenggarakan pelayanan publik memiliki informasi yang lebih banyak sehingga dapat membuat keputusan akan kebijakan yang hanya mementingkan pemerintah dan penguasa serta mengabaikan kepentingan dan kesejahteraan rakyat.

Dalam era otonomi daerah agency problem semakin dirasakan dalam pemerintahan daerah sebagai ujung tombak pembangunan kesejahteraan rakyat daerah, hal ini terjadi karena penyelenggara pemerintah dituntut untuk melayani masyarakat atau pelayanan publik yang makin baik dan tuntutan sosial yang semakin tinggi. Disisi lain terdapat juga tuntutan dari pemerintahan diatasnya yang menuntut kemandirian daerah dalam bidang keuangan. Hal tersebut menyebabkan pemerintah harus memilih menggunakan dana untuk investasi dalam rangka meningkatkan pendapatan atau untuk membiayai fasilitas publik.

\section{Teori Organisasi (Birokrasi dan Organisasi Publik)}

Organisasi publik menurut Gullick dalam Kurnia (2010) adalah organisasi yang mewadahi seluruh lapisan masyarakat dengan ruang lingkup negara atau daerah yang mempunyai kewenangan yang absah (terlegitimasi) di bidang politik, administrasi pemerintahan dan hukum secara terlembaga sehingga mempunyai kewajiban melindungi warga negaranya, melayani keperluannya dan sebaliknya berhak pula memungut pajak untuk pendanaan serta menjatuhkan hukuman sebagai sanksi penegakan peraturan.

\section{Teori Pertumbuhan Ekonomi Regional dan Produk Domestik Regional Bruto}

Pada saat ini tidak ada satupun teori yang mampu menjelaskan pembangunan ekonomi daerah secara komprehensif, namun beberapa teori secara parsial dapat membantu untuk memahami arti penting pembangunan ekonomi daerah dan teori-teori yang membahas tentang faktor-faktor yang menentukan pertumbuhan ekonomi daerah. Menurut Najiah 
(2013) salah satu alat untuk mengukur tingkat kemakmuran dan kesejahteraan yaitu dengan produk domestik regional bruto. Produk domestik regional bruto sering menjadi indikator untuk melihat gejala pertumbuhan ekonomi daerah karena didalamnya mencerminkan kegiatan produksi barang dan jasa di daerah tertentu. Produk domestik regional bruto menurut Badan Pusat Statistik (BPS) didefinisikan sebagai jumlah nilai tambah yang dihasilkan oleh seluruh unit usaha dalam suatu wilayah, atau merupakan jumlah seluruh nilai barang jasa akhir yang dihasilkan oleh seluruh unit ekonomi di suatu wilayah. Produk Domestik regional Bruto disajikan dalam laporan dalam dua harga yaitu PDRB harga konstan dan harga berlaku.

\section{Produk Domestik Regional Bruto (PDRB) dan Pertumbuhan Ekonomi Regional}

Pemerintah daerah merupakan salah satu organisasi sektor publik yang melaksanakan akuntansi sektor publik. Menurut Mardiasmo (2009) ada beberapa komponen lingkungan yang mempengaruhi akuntansi sektor publik. Komponen lingkungan yang mempengaruhi organisasi sektor publik salah satunya faktor ekonomi. Pertumbuhan ekonomi diukur dari perkembangan Gross Domestic Product dan untuk daerah diukur dengan Produk Domestik Regional Bruto (PDRB). Menurut Arsyad (1999) pertumbuhan ekonomi dapat juga diartikan sebagai kenaikan Gross Domestic Product (GDP) atau Gross National Product (GNP) tanpa memandang apakah kenaikan itu lebih besar atau lebih kecil dari tingkat pertumbuhan penduduk atau apakah perubahan struktur ekonomi terjadi atau tidak. Jadi antara pertumbuhan ekonomi dan GDP tidak dapat dipisahkan. Jumlah angka produk domestik regional bruto merupakan hasil akumulasi produksi barang dan jasa di suatu wilayah selama satu tahun anggaran. PDRB ini disajikan oleh setiap pemerintah daerah baik kabupaten maupun propinsi.

\section{Pendapatan Asli Daerah, Investasi Pemerintah dan Angkatan Kerja}

PAD menunjukkan kemampuan daerah untuk membiayai pelaksanaan kekuasaan/kewenangan yang dimilikinya dan merupakan salah satu faktor pendukung yang menentukan keberhasilan pelaksanaan otonomi di daerah (Riduansyah 2003). Hal tersebut sejalan dengan pendapat Hidayat (2007) yang menyatakan bahwa PAD merupakan barometer utama atas suksesnya pelaksanaan otonomi daerah dan diharapkan dengan adanya otonomi daerah maka kemandirian daerah akan terwujud. Menurut Wahyu (2014) pemerintah daerahlah yang paling berperan dalam mengelola pendapatan asli daerah sehingga dapat sepenuhnya digunakan untuk menggerakkan roda perekonomian.

Menurut Makmun dan Yasin (2003) investasi adalah kata kunci penentu laju pertumbuhan ekonomi karena disamping akan mendorong kenaikan output secara signifikan juga secara otomatis akan meningkatkan input sehingga pada gilirannya akan meningkatkan kesempatan kerja dan kesejahteraan masyarakat. Investasi diartikan sebagai pengeluaran atau perbelanjaan penanam-penanam modal atau perusahaan untuk membeli barang-barang modal dan perlengkapan-perlengkapan produksi untuk menambah kemampuan memproduksi barang dan jasa yang tersedia dalam perekonomian sehingga investasi disebut juga dengan penanaman modal (Sukirno 2010). Menurut Suparmoko (2002) tenaga kerja adalah penduduk pada usia kerja yaitu antara 15-64 tahun. Yang dimaksud dengan angkatan kerja adalah bagian dari tenaga kerja yang terlibat atau masih berusaha untuk terlibat dalam kegiatan produktif yang menghasilkan barang dan jasa. Menurut Sugiyanto (2010) salah satu indikator kemajuan ekonomi suatu negara dapat dilihat dari GDP. Laju pertumbuhan ekonomi harus dikaitkan dengan laju pertumbuhan penduduk karena pada prinsipnya pertumbuhan ekonomi harus dinikmati oleh seluruh penduduk. Menurut Gravitiani (2006) penciptaan kesempatan kerja baru berarti adanya 
penciptaan pendapatan masyarakat yang akan mendorong daya beli masyarakat. Penciptaan kesempatan kerja baru juga dapat mendorong induced invesment yang pada akhirnya akan mendorong pertumbuhan ekonomi daerah. Todaro (2004) menjelaskan bahwa kelebihan pekerja merupakan kesempatan dan bukan masalah. Selanjutnya dijelaskan pula bahwa ada dua sektor didalam perekonomian negara yang sedang berkembang yaitu sektor modern dan sektor tradisional. Sektor tradisional tidak hanya berupa sektor pertanian di pedesaan, melainkan juga termasuk sektor informal diperkotaan (pedagang kaki lima, pengecer, pedagang angringan.

\section{Asset Daerah dan Jumlah SKPD}

Standar Akuntansi Pemerintahan dalam PSAP 07-1 mendefinisikan aset adalah sumber daya ekonomi yang dikuasai dan/atau dimiliki oleh pemerintah sebagai akibat dari peristiwa masa lalu dan dari mana manfaat ekonomi dan/atau sosial di masa depan diharapkan dapat diperoleh. Aset daerah merupakan sumberdaya penting bagi pemerintah daerah sebagai penopang utama pendapatan asli daerah.

Menurut Sukarno (2013) sejak bergulirnya reformasi birokrasi yang bertujuan untuk mewujudkan pelaksanaan kepemerintahan yang baik. Birokrasi yang ada saat ini masih saja terlihat gemuk, miskin tugas dan fungsi namun kaya akan struktur. Dalam PP No. 41 Tahun 2007 disebutkan desain struktur kelembagaan di daerah, secara konseptual sudah merupakan pengejawantahan teori-teori organisasi yang sudah dikenal selama ini. Dampak dari carut marutnya kualitas kebijakan dalam bentuk produk perundang-undangan yang tidak komprehensif dan sinerji dan diperkuat lagi dengan adanya intervensi politik atau lebih dikenal kebijakan pimpinan, semakin memperparah kondisi negara saat ini karena semakin gemuknya birokrasi maka akan semakin banyak menyerap anggaran. Anggaran yang dikelolah oleh pemerintah lebih banyak dihabiskan pada belanja pegawai bukannya pada belanja pembangunan untuk rakyat.

\section{KERANGKA BERPIKIR DAN PENGEMBANGAN HIPOTESIS}

Hasil penelitian Madona (2013); Najiah (2013); Suryono (2010); Suryono (2010) menyebutkan bahwa (PAD) berpengaruh secara signifikan terhadap PDRB. Pendapatan asli daerah signifikan dengan nilai elastisitas 0,47 atas PDRB di Jawa Barat merupakan hasil penelitian dari Indah (2011). Hasil penelitian Sugeng (2014) menunjukkan PAD memiliki pengaruh signikan terhadap pertumbuhan ekonomi. Penelitian Hariyanto dan Adi (2007) yang dikutip oleh Mubaroq (2013) juga menemukan bahwa pendapatan asli daerah sangat berpengaruh terhadap pertumbuhan ekonomi, tetapi pertumbuhan yang terjadi masih kurang merata sehingga banyak ketimpangan/jarak ekonomi antar daerah. Fjeldstad (2012) yang melakukan penelitian di Anglophone Africa menyatakan bahwa mobilisasi pendapatan daerah mempengaruhi pertumbuhan ekonomi. Peningkatan pendapatan pemerintah lokal ditujukan untuk pengembangan pelayanan publik dan perkembangan penduduk yang tinggi.

Menurut penelitian Rustiono (2008) angkatan kerja, investasi swasta (PMA dan PMDN) dan belanja pemerintah daerah berpengaruh terhadap PDRB Propinsi Jawa Tengah.. Hasil tersebut sejalan dengan milik Sugeng (2014) yang menyatakan bahwa faktor konsumsi, tabungan, pengeluaran pemerintah dan angkatan kerja berpengaruh positif tetapi tidak signifikan terhadap PDRB, Hasil penelitian Sitompul (2007) juga menyebutkan bahwa investasi pemerintah dan jumlah tenaga kerja berpengaruh positif dan signifikan tehadap PDRB di Sumatera Utara. Menurut Indah (2011) PAD dan tenaga kerja berpengaruh signifikan terhadap PDRB dan pertumbuhan ekonomi di Jawa Barat. 
Demikian pula menurut Fjeldstad (2014) local goverment revenue berpengaruh terhadap pertumbuhan ekonomi lokal.

Phetsavong (2012) juga menyatakan terdapat pengaruh positif investasi publik dan investasi domestik pada Gross Domestic Product pada tingkat dan toleransi tertentu serta berbeda antar negara di Asia. Hasil berbeda ada pada penelitian Mohsin dan Mahmod (1997) yang menjelaskan bahwa investasi pemerintah memberikan pengaruh positif namun masih sangat kecil dibandingkan dengan investasi swasta. Sebaliknya hasil penelitian Hamalinen (2007) justeru mengungkapkan bahwa investasi pemerintah tidak berpengaruh terhadap GDP di Turki. Demikian juga dengan hasil penelitian Madona (2011) investasi tidak signifikan terhadap PDRB di Sumatera Barat. Hasil berbeda di sajikan oleh Afrizal (2013) yang menyebutkan bahwa investasi PMDN dan PMA berpengaruh positif terhadap PDRB di Sulawesi Selatan sedangkan belanja pemerintah dan tenaga kerja berpengaruh negatif dan signifikan terhadap PDRB di Propinsi Sulawesi Selatan.Menurut penelitian Sodik dalam Suindyah (2009) diketahui bahwa angkatan kerja berpengaruh signifikan terhadap pertumbuhan ekonomi dengan tanda negatif, hal ini menyiratkan bahwa daerah belum mampu menyerap angkatan kerja yang ada untuk bisa meningkatkan PDRB.

Berdasarkan hasil penelitian terdahulu dan uraian diatas maka hipotesis yang dirumusakan adalah:

Hipotesis 1 : adanya pengaruh pendapatan asli daerah terhadap pertumbuhan ekonomi kabupaten/kota di Pulau Jawa

Hipotesis 2 : ada pengaruh positif investasi pemerintah daerah terhadap pertumbuhan ekonomi kabupaten/kota di Pulau Jawa.

Hipotesis 3 : angkatan kerja berpengaruh positif terhadap pertumbuhan ekonomi

\section{METODE PENELITIAN}

\section{Jenis dan Sumber Data}

Pendekatan penelitian yang digunakan ialah pendekatan kuantitatif. Dalam penelitian ini terdiri satu variabel terikat, tiga variabel bebas dan dua variabel kontrol. Alat analisis yang dipakai adalah analisis regresi berganda. Jenis data yang digunakan dalam penelitian ini adalah data sekunder yang bersumber dari: (1) Laporan Hasil Pemeriksaan Laporan Keuangan Pemerintah Daerah Tahun 2011 dari Badan Pemeriksa Keuangan Republik Indonesia; (2) Badan Pusat Statistik dalam profil Pembangunan Propinsi Jawa Timur, Jawa Tengah, DI Yogyakarta, Banten, dan Jawa Barat (3) Profil tiap Kabupaten/Kota yang ada di Pulau Jawa.

\section{Pengumpulan Data dan Pemilihan Sampel}

Populasi adalah wilayah generalisasi yang terdiri atas obyek/subyek yang mempunyai kualitas dan karakteristik tertentu yang ditetapkan penelti untuk dipelajari dan kemudian ditarik kesimpulan (Sugiyono 2002). Metode pengumpulan data dalam penelitian ini ialah teknik sampling secara purposive sampling. Data yang digunakan untuk penelitian adalah data time series. Populasi dalam penelitian ini adalah semua kabupaten/kota di Jawa. Terdapat 112 kabupaten/kota di Pulau Jawa namun dalam penelitian ini tidak semua dijadikan sampel karena data tidak lengkap. Pada akhirnya peneliti menggunakan 84 kabupaten/kota untuk menjadi sampel, pengambilan data untuk sampel selama 2 tahun yaitu tahun 2010 dan 2011. Jadi jumlah sampel sebanyak 168. Data PAD, investasi pemerintah dan jumlah asset daerah diambil dari LKPD kabupaten/kota tahun 2010-2011 yang telah diperiksa dan dirilis Badan Pemeriksa 
Keuangan Republik Indonesia (BPK-RI) Tahun 2012. Data angkatan kerja dan PDRB diperoleh dari data Badan Pusat Statistik yang terdapat ada Profil Pembangunan Propinsi Jawa Timur, Profil Pembangunan Propinsi DI Yogyakarta, Profil Pembangunan Propinsi Banten, Profil Pembangunan Propinsi Jawa Tengah dan Profil Pembangunan Propinsi Jawa Barat, Jumlah SKPD yang diperoleh dari LKPD tiap-tiap kabupaten/kota dan dari profil masing-masing kabupaten/kota di Pulau Jawa.

\section{Definisi Operasional dan Pengukuran Variabel}

1. Variabel Bebas (Independent Variables)

a. Pendapatan asli daerah ialah realisasi pendapatan daerah yang diperoleh kabupaten/kota di Pulau Jawa Tahun 2010 dan 2011 dinyatakan dalam satuan rupiah. Jumlah PAD tersebut terdapat pada Laporan Realisasi Anggaran masingmasing kabupaten/kota.

b. Investasi pemerintah ialah jumlah total dari ekuitas dana investasi pemerintah daerah yang terdapat dalam neraca kabupaten/kota tahun 2010 s.d. 2011dan dinyatakan dalam satuan rupiah.

c. Angkatan kerja adalah jumlah penduduk usia kerja yaitu melakukan kegiatan ekonomi yang menghasilkan barang/jasa secara kontinu dan dinyatakan dalam satuan orang/jiwa.

2. Variabel Terikat/Tergantung (Dependent Variables)

Variabel terikat dalam penelitian ini adalah PDRB. Produk domestik regional bruto ialah jumlah barang dan jasa yang mampu diproduksi oleh pemerintah daerah dan dilaporkan oleh pemerintah daerah kabupaten/kota di Propinsi Jawa Timur, Jawa Tengah, DI Yogyakarta, Jawa Barat, dan Banten atas dasar harga berlaku tahun 2010 sampai dengan 2011 dan dinyatakan dalam satuan rupiah.

3. Variabel Kontrol

a. Asset daerah ialah seluruh asset milik pemerintah daerah kabupaten/kota baik berupa aset lancar, investasi jangka panjang, aset tetap dan aset lainnya yang disajikan dalam Neraca Tahun 2010 sampai dengan 2011. Asset tersebut dinyatakan dalam satuan rupiah.

b. Jumlah SKPD ialah seluruh perangkat daerah mulai sekretaris daerah, Sekretaris DPRD, bagian-bagian, kantor, dinas, dan kecamatan. Data ini dinyatakan dalam unsur .bagian SKPD disajikan dalam bentuk angka numerik bulat.

\section{Teknik Analisis Data}

Teknik analisis yang digunakan adalah analisis regresi linear berganda dengan SPSS. Pengujian dilakukan setelah hipotesis asumsi klasik telah terpenuhi. Untuk mengetahui pengaruh PAD, investasi daerah dan angkatan kerja terhadap pertumbuhan ekonomi kabupaten/kota di Jawa yang disertai dengan variabel kontrol, maka model analsisis yang digunakan yaitu:

Persamaan $($ dengan memasukkan variabel kontrol $)=$

$$
\text { Yit }=\beta 0+\beta 1 \text { PADit }+\beta 2 \text { IPit }+\beta 3 \text { KRJit }+\beta 4 \text { ADit }+\beta 5 \text { SKPDit }+ \text { eit }
$$

Dimana

$\mathrm{i} \quad=1,2,3, \ldots \ldots, \mathrm{N}$ (dimensi cross section)

$\mathrm{t} \quad=1,2,3, \ldots \ldots, \mathrm{T}$ (dimensi time series) 


$\begin{array}{ll}\mathrm{Y} & =\text { PDRB } \\ \mathrm{PAD} & =\text { Pendapatan Asli Daerah } \\ \mathrm{IP} & =\text { Investasi Pemerintah } \\ \mathrm{AK} & =\text { Angkatan Kerja } \\ \mathrm{AD} & =\text { Asset Daerah } \\ \mathrm{SKPD} & =\text { Jumlah SKPD } \\ \beta 0 & =\text { Konstanta } \\ \beta 1,2,3,4,5 & =\text { Koefesien Regresi masing-masing variabel } \\ \varepsilon & =\text { Term Error }\end{array}$

Untuk memudahkan pembacaan parameter/koefisien regresi sebagai elastisitas maka persamaan diatas ditransformasikan kedalam bentuk logaritma natural menjadi :

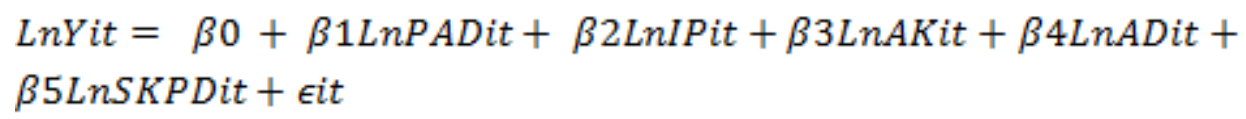

1. Uji asumsi klasik

Adapun uji asumsi klasik yang digunakan adalah normalitas, multikolinearitas dan heteroskedastisitas. Uji normalitas dalam penelitian ini menggunakan SPSS 18 dengan melakukan regresi uji grafik dengan melihat normal probability plot. Untuk melengkapi uji normalitas residual selain dengan grafik juga menggunakan uji statistik. Dalam penelitian ini uji statistik yang dilakukan berdasarkan nilai kosmogorovSmirnov Test. Dalam mendeteksi multikolinearitas dapat dilihat dari (1) nilai tolerence dan lawannya (2) variance inflation factor (VIF). Nilai cutoff yang umum menunjukkan adanya multikolinearitas adalah Tolerance $<0,10$ atau sama dengan VIF $>10$.. Metode yang digunakan adalah scatter plot. Deteksi ada tidaknya heteroskedastisitas dapat dilakukan dengan melihat ada tidaknya pola tertentu pada grafik scatterplot. Setelah dengan metode grafik maka akan diadakan juga metode uji statistik dengan uji Park.

2. Uji Hipotesis

Pengujian ini dilakukan dengan menggunakan tingkat signifikansi $0,05(\alpha=$ 5\%) dalam pengujian uji t. Uji signifikansi parameter individu (uji statistik t) dilakukan untuk mengetahui apakah variabel independen secara individu mempengaruhi variabel dependen. Uji ini untuk menganalisis hipotesis 1,2 dan 3 .

\section{HASIL DAN PEMBAHASAN}

Uji Asumsi Klasik

\section{Uji Normalitas}

Uji normalitas dengan uji grafik digunakan untuk melihat normal probability plot. Dari gambar probability plot diketahui bahwa pola yang terjadi data menyebar disekitar garis diagonal dan mengikuti arah garis diagonal sehingga memenuhi asumsi normalitas. uji normalitas statistik nonparametrik dari uji Kolmogorov-Smirnov (KS) hasilnya diketahui bahwa besarnya nilai Kolmogorov-Smirnov 1,003 dan signifikan pada 0,267 hal ini menunjukkan bahwa residual terdistribusi normal sehingga uji regresi dapat dilakukan. 
2. Uji Multikolinearitas

Uji Dalam mendeteksi multikolinearitas dapat melihat pada tabel berikut ini:

Tabel 1

Uji Multikolinearitas

Coefficients $^{a}$

\begin{tabular}{|c|c|c|c|c|c|c|c|c|}
\hline \multirow{2}{*}{\multicolumn{2}{|c|}{ Model }} & \multicolumn{2}{|c|}{$\begin{array}{c}\text { Unstandardized } \\
\text { Coefficients }\end{array}$} & \multirow{2}{*}{$\begin{array}{c}\text { Standardized } \\
\text { Coefficients } \\
\text { Beta }\end{array}$} & \multirow[b]{2}{*}{$\mathrm{t}$} & \multirow[b]{2}{*}{ Sig. } & \multicolumn{2}{|c|}{ Collinearity Statistics } \\
\hline & & $\mathrm{B}$ & Std. Error & & & & Tolerance & VIF \\
\hline \multirow[t]{2}{*}{1} & (Constant) & $-2,648$ & 946 & & $-2,800$ &, 006 & & \\
\hline & $\begin{array}{l}\text { InPAD } \\
\text { InIP } \\
\text { InAD } \\
\text { InAK } \\
\text { InSKPD }\end{array}$ & $\begin{array}{r}, 554 \\
-, 201 \\
, 593 \\
, 188 \\
, 985\end{array}$ & $\begin{array}{l}, 061 \\
, 178 \\
, 188 \\
, 050 \\
, 144\end{array}$ & $\begin{array}{r}, 506 \\
-, 140 \\
, 397 \\
, 200 \\
, 380\end{array}$ & $\begin{array}{r}9,121 \\
-1,133 \\
3,157 \\
3,751 \\
6,831\end{array}$ & $\begin{array}{l}, 000 \\
, 259 \\
, 002 \\
, 000 \\
, 000\end{array}$ & $\begin{array}{l}, 877 \\
, 176 \\
, 170 \\
, 948 \\
, 871\end{array}$ & $\begin{array}{l}1,141 \\
5,690 \\
5,871 \\
1,055 \\
1,148\end{array}$ \\
\hline
\end{tabular}

Dari hasil sebagian regresi menunjukkan bahwa semua variabel telah bebas dari multikolinearitas. Berdasarkan pada nilai tolerance dan VIF terlihat bahwa tidak ada nilai tolerance dibawah 0,10 (nilai tolerance berkisar antara 0,170 sampai 0,948 ), begitu juga dengan nilai VIF tidak ada yang diatas 10 (nilai VIF berkisar antara 1,055 sampai 5,871). Jadi terbukti bahwa tidak ada multikolinearitas yang serius.

\section{Uji Heterokedastisitas}

Metode yang digunakan untuk menguji asumsi klasik heteroskedastisitas adalah uji grafik dan uji statistik yaitu Uji Park. Metode ini dilakukan dengan melihat grafik plot. Dari gambar Grafik Scatterplot Heterokedastisitas diketahui bahwa hasil hasil regresi tidak ada pola tertentu yang jelas terlihat dan titik-titik menyebar diatas dan dibawah angka 0 pada sumbu Y secara acak. Jadi berdasarkan gambar diatas disimpulkan tidak terjadi Heterokedastisitas.

\section{Uji Statistik}

1. Koefisien Determinasi

Tabel 2

Koefisien Deteminasi

\begin{tabular}{|c|c|c|c|c|}
\hline \multirow{2}{*}{$\begin{array}{r}\text { Mo } \\
\text { Model }\end{array}$} & \multirow[b]{2}{*}{$\mathrm{R}$} & \multirow{2}{*}{\multicolumn{2}{|c|}{$\begin{array}{l}\text { Adjusted R } \\
\text { Square }\end{array}$}} & \multirow[b]{2}{*}{$\begin{array}{l}\text { Std. Error of the } \\
\text { Estimate }\end{array}$} \\
\hline & & & & \\
\hline 1 &, $751^{a}$ & ,563 & ,550 & 40056 \\
\hline
\end{tabular}

a. Predictors: (Constant), InSKPD, InAK, InIP, InPAD, InAD

b. Dependent Variable: InPDRB

Tampilan output SPSS model summary menunjukkan besarnya adjusted $\mathrm{R}^{2}$ sebesar 0,55, hal ini berarti $55 \%$ PDRB dapat dijelaskan oleh 5 variabel independen yaitu PAD, investasi pemerintah, angkatan kerja, jumlah aset daerah, dan jumlah SKPD, sedangkan sisanya sebanyak $45 \%$ dijelaskan oleh faktor-faktor lain diluar model. Standar error of estimate (SEE) sebesar 0,40056, makin kecil nilai SEE akan membuat model regresi semakin tepat dalam memprediksi variabel dependen.

2. Uji signifikansi parameter Individual (Uji statistik t) 
Uji statistik $\mathrm{t}$ pada dasarnya menunjukkan seberapa jauh pengaruh satu variabel independen terhadap variabel dependen dengan menganggap variabel independen lainnya konstan. Uji dilakukan untuk menjawab H1, H2 dan H3.

Tabel 3

Uji Statistik T Parsial

Coefficients $^{a}$

\begin{tabular}{|c|c|c|c|c|c|c|c|c|}
\hline \multirow{2}{*}{\multicolumn{2}{|c|}{ Model }} & \multicolumn{2}{|c|}{$\begin{array}{l}\text { Unstandardized } \\
\text { Coefficients }\end{array}$} & \multirow{2}{*}{$\begin{array}{c}\begin{array}{c}\text { Standardiz } \\
\text { ed } \\
\text { Coefficients }\end{array} \\
\text { Beta }\end{array}$} & \multirow[b]{2}{*}{$t$} & \multirow[b]{2}{*}{ Sig. } & \multicolumn{2}{|c|}{ Collinearity Statistics } \\
\hline & & $\mathrm{B}$ & Std. Error & & & & Tolerance & VIF \\
\hline 1 & (Constant) & $-2,648$ & 946 & & $-2,800$ & ,006 & & \\
\hline & $\begin{array}{l}\text { InPAD } \\
\text { InIP } \\
\text { InAD } \\
\text { InAK } \\
\text { InSKPD }\end{array}$ & $\begin{array}{r}, 554 \\
-, 201 \\
, 593 \\
, 188 \\
, 985\end{array}$ & $\begin{array}{l}, 061 \\
178 \\
, 188 \\
, 050 \\
, 144\end{array}$ & $\begin{array}{r}, 506 \\
-, 140 \\
, 397 \\
, 200 \\
, 380\end{array}$ & $\begin{array}{r}9,121 \\
-1,133 \\
3,157 \\
3,751 \\
6,831\end{array}$ & $\begin{array}{l}, 000 \\
, 259 \\
, 002 \\
, 000 \\
, 000\end{array}$ & $\begin{array}{l}, 877 \\
, 176 \\
, 170 \\
, 948 \\
, 871\end{array}$ & $\begin{array}{l}1,141 \\
5,690 \\
5,871 \\
1,055 \\
1,148\end{array}$ \\
\hline
\end{tabular}

a. Dependent Variable: InPDRB

Adapun hasil output analisis regresi berganda dari tabel 4 dapat dituliskan dalam model regresi linear berganda sebagai berikut :

$$
\mathrm{Y}=\text {-2,648 + 554 PAD - 0,201 IP + 0,593 AD + 0,188 AK + 0,985 SKPD }
$$

Dari hasi output SPSS diatas dapat disimpulkan beberapa hal, antara lain:

a. Konstanta adalah -2,648 menunjukkan apabila seluruh variabel independen tidak berpengaruh sama sekali (dalam keadaan nol) maka variabel dependen (PDRB) akan bernilai sebesar $-2,648$.

b. Hasil uji t statistik menunjukkan bahwa variabel independen PAD berpengaruh terhadap PDRB secara positif dan signifikan pada tingkat $0,000<0,05$. Arah hubungan antara PAD dan PDRB positif sebesar 0,554 sehingga menandakan bahwa apabila PAD meningkat searah dengan meningkatnya jumlah PDRB. Jika Jumlah PAD meningkat 1 persen kemungkinan PDRB akan meningkat 0,554 persen. Berdasakan hasil uji t ini berarti H1 diterima.

c. Variabel independen Investasi Pemerintah (IP) setelah diadakan analisis uji $\mathrm{t}$ ternyata tidak memiliki pengaruh terhadap PDRB. Hal ini terbukti dengan tidak signifikannya hasil uji statistik yang lebih besar dari tingkat probabilitas yaitu 0.259 $>0.05$. Berdasarkan hasil analisis disimpulkan bahwa $\mathrm{H} 2$ ditolak.

d. Hasil uji t statistik parsial menunjukkan bahwa variabel independen Angkatan Kerja berpengaruh terhadap PDRB secara positif dan signifikan pada tingkat 0,000 $<0,05$. Koefisien Regresi bernilai positif sebesar 0,188 menunjukkan arah positif antara angkatan kerja dengan PDRB. Semakin meningkat jumlah tenaga kerja maka akan ada peningkatan PDRB kabupaten/kota di Jawa. Berdasarkan hasil statistik tersebut dapat diambil kesimpulan bahwa $\mathrm{H} 3$ diterima.

e. Hasil dari analisis uji t dengan memasukkan variabel kontrol diketahui bahwa variabel kontrol $A D$ berpengaruh terhadap PDRB secara positif dan signifikan pada tingkat 0,002 dibawah 0,05 dan mempunyai koefisen sebesar 0,593.

f. Hasil uji t statistik terhadap variabel kontrol kedua yaitu jumlah SKPD, menghasilkan adanya pengaruh jumlah SKPD terhadap PDRB. Hal ini terbukti dengan tingkat signifikansi 0,000 dibawah 0,05. 
Pada Penelitian ini mencoba menguji agency teori dan teori ekonomi regional terkait dengan pengaruh pendapatan asli daerah, investasi pemerintah, angkatan kerja, jumlah aset daerah dan jumlah SKPD terhadap PDRB kabupaten/kota di Jawa.

1. Pengaruh Pendapatan Asli Daerah (PAD) dengan Produk Domestik Regional Bruto (PDRB) Kabupaten/Kota di Jawa

Berdasarkan analisis regresi berganda dengan uji t parsial yang menyatakan ada pengaruh yang signifikan antara pendapatan asli daerah terhadap produk domestik regional bruto terbukti. Jadi dapat disimpulkan bahwa hipotesis ke-1 diterima, hal ini terbukti dengan hasil statistik uji t sebesar 9,121 dan tingkat signifikansi $0,000<0,05$.

Hasil pengujian ini mendukung penelitian Madona (2013); Najiah (2013); Indah (2011); Sugeng (2014); Pujiati (2007); Suryono (2010) yang menunjukkan bahwa terdapat pengaruh yang positif antara pendapatan asli daerah (PAD) dengan produk domestik regional bruto (PDRB) atau dengan pertumbuhan ekonomi. Pada lampiran 7 membuktikan bahwa Kota Banjar yang memiliki pendapatan asli daerah relatif rendah yaitu Rp. 37,36 milyar menghasilkan produk domestik regional bruto hanya Rp. 1770 juta sedangkan Kabupaten Sleman yang pendapatan asli daerahnya berjumlah Rp. 911,79 milyar mempunyai produk domestik bruto relatif besar yaitu Rp 13.612 milyar.

Hasil ini dapat dijadikan pertimbangan oleh pemerintah kabupaten/kota untuk terus menggali dan mengelola sumber daya alamnya secara profesional, efisien, dan efektif. Hasil Penelitian Fjeldstad (2012) di Anglophone Africa menyatakan bahwa mobilisasi pendapatan daerah mempengaruhi pertumbuhan produksi barang dan jasa dan pada akhirnya ikut meningkatkan pertumbuhan ekonomi wilayah lokal setempat. Implikasi penelitian ini dengan adanya pengaruh PAD terhadap PDRB adalah semakin tinggi pendapatan asli daerah maka terdapat kecenderungan peningkatan pemerintah daerah untuk menghasilkan produksi barang dan jasa yang diukur dengan PDRB. Kondisi ini sesuai dengan teori pertumbuhan ekonomi regional bruto. Hasil ini dapat dijadikan pertimbangan oleh pemerintah kabupaten/kota untuk terus menggali dan mengelola sumber daya alamnya secara profesional, efisien, dan efektif. Hasil Penelitian Fjeldstad (2012) di Anglophone Africa menyatakan bahwa mobilisasi pendapatan daerah mempengaruhi pertumbuhan produksi barang dan jasa dan pada akhirnya ikut meningkatkan pertumbuhan ekonomi wilayah lokal setempat. Peningkatan pendapatan pemerintah lokal ditujukan untuk pengembangan pelayanan publik dan perkembangan penduduk yang tinggi.

2. Pengaruh Investasi Pemerintah dengan Produk Domestik Regional Bruto (PDRB) Kabupaten/Kota di Jawa

Berbeda dengan hasil analisis hipotesis ke-1, pada hipotesis kedua ini menunjukkan hasil bahwa hipotesis ditolak. Analisis regresi berganda dengan uji t menunjukkan bahwa investasi pemerintah tidak berpengaruh terhadap produk domestik regional bruto dengan tingkat signifikansi diatas 0,05 yakni sebesar 0,259 dengan hasil uji $\mathrm{t}$ sebesar -1,133. Hasil ini sesuai dengan temuan penelitian Hamalinen (2007) yang mengungkapkan bahwa investasi pemerintah tidak berpengaruh terhadap GDP di Turki. Demikian juga dengan hasil dari Yunarko (2007) yang menyebutkan bahwa investasi tidak berpengaruh signifikan terhadap PDRB Jawa Tengah. 
Implikasi hipotesis ke-2 tentang pengaruh investasi pemerintah daerah terhadap PDRB ialah bahwa walaupun pemerintah daerah menggunakan dana yang dimiliki untuk menambah investasi tidak menjamin peningkatan produksi barang dan jasa daerah tersebut. Investasi pemerintah tersebut ditujukan sebagian besar untuk kepentingan publik. Hasil ini memang membuktikan telah ada agency problem dalam pemerintahan. Investasi pemerintah daerah tidak berpengaruh karena ditujukan untuk keperluan investasi pelayanan publik dan yang berpengaruh adalah investasi PMA (Penanaman Modal Asing) atau investasi swasta dalam negeri. Investasi pemerintah tersebut ditujukan sebagian besar untuk kepentingan publik guna menghindari agency problem dalam pemerintahan sehingga tidak dapat menambah produk domestik regional bruto.

3. Pengaruh Angkatan Kerja dengan Produk Domestik Regional Bruto (PDRB) Kabupaten/Kota di Jawa

Hipotesis yang menyebutkan bahwa ada pengaruh angkatan kerja terhadap produk domestik regional bruto diterima karena dari hasil uji parsial diketahui bahwa tingkat signifikansinya lebih kecil dari 0,05 yakni sebesar 0,00 dengan uji t 3,751. Hasil pengujian ini mendukung hasil penelitian dari Suryono (2010); Najiah (2013); Sitompul (2007) yang menemukan bahwa terdapat pengaruh positif dan signifikan angkatan kerja terhadap produk domestik regional bruto. Hasil penelitian yang sejalan yaitu Hasan (2012); Nizar (2013); diketahui bahwa tenaga kerja berpengaruh positif pada pertumbuhan ekonomi di Indonesia.

Hasil penelitian atas hipotesis ke-3 ialah adanya pengaruh peningkatan jumlah angkatan kerja terhadap PDRB memiliki kecenderungan peningkatan pemerintah daerah untuk menghasilkan produksi barang dan jasa jika jumlah tenaga kerjanya tinggi. Kondisi ini sesuai dengan teori pertumbuhan ekonomi regional bruto. Pada keadaan sekarang, angkatan kerja yang tinggi menyebabkan PDRB meningkat bukan karena jumlah tetapi dipengaruhi perkembangan beberapa faktor. Faktor-faktor tersebut antara lain tingkat pendidikan, perkembangan teknologi dan pergeseran pola pikir dari masyarakat tradisional kearah modern.

4. Pengaruh Aset Daerah dengan Produk Domestik Regional Bruto (PDRB) Kabupaten/Kota di Jawa

Analisis statistik uji $\mathrm{t}$ aset daerah terhadap PDRB menghasilkan bahwa terdapat pengaruh aset daerah terhadap PDRB. Pengaruh tersebut dibuktikan hasil uji t 3,157 dengan tingkat signifikasi 0,002 dibawah 0,05.

Manajemen aset daerah memang menjadi paradigma baru dalam era desentralisasi. Pengelolaan aset yang cerdas akan menghasilkan penerimaan bagi daerah. Pengelolaan aset ini mulai dari inventarisasi, cara perolehan/perbaikan, penggunaan dan pengawasan atau pengendalian harus sebaik mungkin karena dapat memunculkan berbagai masalah. Aset yang banyak dan dikelola dengan baik dapat ikut meningkatkan pendapatan asli daerah karena produksi barang dan jasa ikut meningkat.

5. Pengaruh Jumlah SKPD dengan Produk Domestik Regional Bruto (PDRB) Kabupaten/Kota di Jawa

Hasil analisis regresi berganda menunjukkan bahwa terdapat pengaruh jumlah SKPD terhadap PDRB, terbukti dengan tingkat signifikansi 0,000 dibawah 0,05 dengan uji t 6,831 . Nilai t positif menunjukkan bahwa jika jumlah SKPD 
bertambah akan berpengaruh pada kenaikan PDRB secara positif juga. Jumlah SKPD yang dihitung dari total sekretaris daerah, bagian-bagian, dinas-dinas dan kecamatan menyebabkan perbedaan antara kota dan kabupaten. Jumlah kecamatan di kota relatif lebih sedikit dibandingkan dengan jumlah kecamatan pada kabupaten. Jumlah SKPD ini sangat menentukan jumlah anggaran yang harus dibagi dan disediakan oleh pemerintah daerah. Semakin banyak jumlah SKPD maka semakin luas wilayah kerja dan makin kompleks penyelenggaraan pemerintah.

Menurut Sukarno (2013) sejak bergulirnya reformasi birokrasi yang bertujuan untuk mewujudkan pelaksanaan pemerintahan yang baik, birokrasi yang ada saat ini masih saja terlihat gemuk, miskin tugas dan fungsi, namun kaya akan struktur. Banyakanya jumlah kecamatan pada kabupaten memang menghasilkan produksi barang dan jasa yang banyak, akan tetapi banyaknya bagian dan dinas justeru memberikan beban anggaran yang besar bagi belanja pegawai. Dalam jumlah SKPD ini memang telah terjadi agency problem bidang pemerintahan di beberapa kabupaten/kota. Menjadikan seseorang sebagai kepala dinas terkadang bukan karena faktor kredibelitas ataupun kinerja yang bagus tetapi karena faktor politik.

\section{KESIMPULAN} yaitu :

Dari hasil analisis dan uraian pada bab sebelumnya maka kesimpulan yang diambil

a. Variabel pendapatan asli daerah memberi pengaruh positif terhadap produk domestik regional bruto

b. Variabel investasi pemerintah tidak berpengaruh secara signifikan terhadap produk domestik regional bruto

c. Variabel angkatan kerja ternyata memiliki pengaruh terhadap produk domestik regional bruto kabupaten/kota di Jawa.

Mengingat adanya keterbatasan penelitian ini maka disarankan untuk memasukkan variabel-variabel lainya dan lebih memperpanjang waktu pengambilan sampel.

\section{DAFTAR PUSTAKA}

Afrizal, Fitrah. 2013. Analisis Pengaruh Tingkat Investasi, Belanja Pemerintah dan Tenaga Kerja Terhadap PDRB di Propinsi Sulawesi Selatan Tahun 2001-2011. Skripsi. UNHAS: Makassar.

Arsyad, Lincolin. 1999. Pengantar Perencanaan dan Pembangunan Ekonomi Daerah. Edisi Pertama. Penerbit BPFE. Yogyakarta.

Chirmay, Teane. 2006. Financial Development Investment Productivity and Economic Growth In The U.S. Morehead State University: Southwestern Economic Review.

Davey, K.J. 1988. Pembiayaan Pemerintah Daerah, Praktek-Praktek International dan Relevansinya Bagi Dunia Ketiga, Penerbit UI Press, Jakarta.

Dritsakis, Nikolaos dan Adamopoulos, Antonis. 2004. A Causal Relationship Between Goverment Spending and Economic Development: An Empirical Examinantion of The Greek Economy. Aplie Economic, 36, 457 - 464.

Fjeldstad, O.H. 2014. Fiscal Desentralisation In Developing Countries: Lessons for Bangladesh. CMI BRIEF. April 2014. Volume 13 No 2.

Fjeldstad, O.H. and Kari H. 2012. Local Goverment Revenue Mobilisation In Anglophone Afrika. CMI Working Paper WP 2012 :6. 
Ghozali, Imam. 2011. Ekonometrika, Teori, Konsep dan Aplikasi dengan SPSS 17. Penerbit Badan Penerbit Universitas Diponegoro. Semarang.

Gravitiani, Evi. 2006. Analisis Shift-Share Dinamik pada Perekonomian Kota Yogyakarta, Gujarati, Damodar, N. 1998. Basic Econometrics, International Edition. Published by Prentice- Hall International, Inc.

Halim, Abdul. 2001. Manajemen Keuangan Daerah. Penerbit UPP Akademi Manajemen Perusahaan YKPN. Yogyakarta.

Hamalainen, Pellervo. 2007. Productivity of public capital. Literatu review and some empirical findings

Hamzah, Muhammad Zilal. 2005. Does Block Grant Generates Economic Growth on Province-Level in Indonesia After The Implementation of Fiscal Decentralization Policy? Simposium Riset Ekonomi II. Surabaya.

Haryanto, Joko Tri. 2005. Analisa Data Alokasi Umum (DAU) Kaitannya Dengan Penciptaan Kemandirian Daerah di Era Otonomi: Studi Kasus 30 Propinsi di Indonesia. Simposium Riset Ekonomi II. Surabaya.

Hornstein.1998. Inventory Investment and The Business Cycle. Federal Reserve Bank Of Richmond Economic Quartely. Volume 84/2 Spring 1998.

Indah, Siska P. 2011. Analisis Dampak Desentralisasi Fiskal dan Pengaruhnya Terhadap PDRB, Tenaga Kerja, dan Kemiskinan di Propinsi Jawa Barat.Institut Pertanian Bogor.

Jhingan, ML. 2000. Ekonomi Perencanaan dan Pembangunan. Edisi Pertama. Penerbit CV Rajawali. Jakarta.

Kementrian Pendayagunaan Aparatur Negara dan Reformasi Birokrasi.2012. Evaluasi Organisasi Pemerintah Daerah. Disampaikan oleh Asisten Deputi Kelembagaan dalam workshop tanggal 22-27 Juli 2012.

Khan, Mohsin S. Dan Manmoham S.Kumar. 1997. Public And Private Investment and The Growth Process In Develoving Countries. Oxford Bulletin Of Economics and Statistics, 59,1, 305-9049.

Kuncoro, Mudrajad. 2006. Otonomi dan Pembangunan Daerah. Penerbit Erlangga. Jakarta.

Kurnia, Chandra. 2010. Teori Organisasi Publik dan Organisasi Serta Manajemen Dalam Pemerintah. Chandraas blog: Senin, 22 Februari 2010.

Madona, Felin. 2011. Analisis Pengaruh Investasi, Pendapatan Asli Daerah (PAD) dan Tenaga Kerja Terhadap PDRB Sumatera Barat. Skripsi. Universitas Andalas: Padang.

Makmun dan Yasin, Akmad. 2003. Pengaruh Investasi dan Tenaga Kerja Terhadap PDB Sektor Pertanian. Kajian Ekonomi. 7(3):57-83.

Mardiasmo. 2009. Akuntansi Sektor Publik. Penerbit Andi. Yogyakarta.

Mubaroq, Muhammad R. Dan Sutyastie. 2013. Pengaruh Investasi Pemerintah, Tenaga Kerja, dan Desentralisasi Fiskal Terhadap Pertumbuhan Ekononomi Kabupaten di Indonesia Tahun 2007-2010. Departemen Ilmu Ekonomi Universitas Padjadjaran..

Najiah, Laeni. 2013. Analisis Pengaruh Pendapatan Asli Daerah, Dana Perimbangan, dan Tingkat Partisipasi Angkatan Kerja Terhadap PDRB di Kota Depok Periode 2001-2010. UIN Syarif Hidayatullah ; Jakarta

Nizar, Chairul dkk. 2013. Pengaruh Investasi Dan Tenaga Kerja Terhadap Pertumbuhan Ekonomi Serta Hubungannya Terhadap Tingkat Kemiskinan di Indonesia. ISSN 2302-0172 pp. $1-8$.

Nurhadi, Habsul. 2013. Pemerintahan Daerah dan Penyusunan Organisasi Perangkat Daerah. Kompasiana: 21 Juli 2013. 
Pancawati, Neni. 2000. Pengaruh Rasio Kapital-Tenaga Kerja, Tingkat Pendidikan, Stok Kapital dan Pertumbuhan Penduduk Terhadap Tingkat Pertumbuhan GDP Indonesia : Jurnal Ekonomi dan Bisnis Indonesia. 15(02) : 268-283.

Pemerintah Propinsi Banten. Profil Pembangunan Propinsi Banten, DI Yogyakarta, Jawa Barat, Profil,Jawa Tengah dan Jawa Timur Tahun 2012

Peraturan Menteri Dalam Negeri Republik Indonesia Nomor 52 Tahun 2012 Tentang Pedoman Pengelolaan Investasi Pemerintah Daerah.

Phetsavong, Kongphet dan Masaru I. 2012. The Impact Of Public and Private Investment On Economic Growth: Evidence From Developing Asian Countries. IDEC Discussion Paper 2012, Hiroshima University.

Prasasti, Diah. 2006. Perkembangan PDRB Per Kapita 30 Propinsi di Indonesia Periode 1993-2003. Pendekatan Disparitas Regional dan Konvergensi. Jurnal Ekonomi dan Bisnis Indonesia. 21(4):334-360.

Pujiati, Amin. 2007. Analisis Pertumbuhan Ekonomi Di Karisidenan Semarang Era Desentralisasi Fiskal. Jurnal Ekonomi Pembangunan, Vol 12 No.03, Desember 2007: Hal 61-70.

Putong, Iskandar. 2003. Ekonomi Mikro dan Makro. Edisi 2. Penerbit Ghalia Indonesia. Jakarta.

Rahardjo, Ari. 2008. Pengaruh Pengeluaran Pemerintah, Investasi Swasta, dan Angkatan Kerja Terhadap Pertumbuhan Ekonomi Tahun 1982-2003 (Studi kasus di Kota Semarang) Tesis, Universitas Diponegoro Semarang.

Rustiono, Deddy. 2008. Analisis Pengaruh Investasi, Tenaga Kerja dan Pengeluaran Pemerintah Terhadap Pertumbuhan Ekonomi di Propinsi Jawa Tengah. Tesis, Universitas Diponegoro Semarang.

Sodik, Jamzani. 2007. Pengeluaran Pemerintah dan Pertumbuhan Ekonomi Regional : Studi Kasus Data Panel Indonesia. Jurnal Ekonomi Pembangunan, Vol 12 No 01, April 2007: 27-36.

Setyaningrum, Dyah dan Febriyani Syafitri. 2012. Analisis Pengaruh karakteristik Pemerintah Daerah Terhadap Tingkat Pengungkapan Laporan Keuangan. Jurnal Akuntansi dan Keuangan Indonesia ; Volume 9 Nomor 2 halaman 154-170.

Sitompul, Novita L. 2007. Analisis Pengaruh Investasi dan Tenaga Kerja Terhadap PDRB Sumatera Utara. Tesis.Universitas Sumatera Utara, Medan.

Sugeng, Wahyu dan Imam Soeparno. 2014. Analisis Indikator Makro Ekonomi Terhadap pertumbuhan Ekonomi Kabupaten/Kota Di Sumatera Utara. ISSN: 2339-210X

Sugiyanto, Catur. 2010. Analisis Indikator Ekonomi. Penerbit PSEKP UGM, Yogyakarta

Sugiyono. 2012. Metode Penelitian Pendidikan Pendekatan Kuantitatif, Kualitatif, dan $R \& D$. Bandung: ALFABETA. 2012 (cet. 15)

Suindyah, Sayekti D. 2009. Pengaruh Investasi, Tenaga Kerja dan Pengeluaran Pemerintah Terhadap Pertumbuhan Ekonomi di Propinsi Jawa Timur. ISSN 14110393. EKUITAS, Akreditasi No. 110/DIKTI/Kep/2009.

Sukarno, Ahmad. 2013. Birokrasi Gemuk, Kepentingan Politik dan Sinerjisitas Peraturan Kelembagaan Daerah. Kompasiana : Birokrasi.

Sukirno, Sadono. 2012. Makro ekonomi Teori Pengantar.Edisi ketiga; PT Raja Grafindo Persada : Jakarta.

Suparmoko, M. 2002. Ekonomika Pembangunan. Jakarta: BPFE

Suryono, Wiratno B. 2010. Analisis Pengaruh Pendapatan Asli Daerah, Tingkat Investasi, dan Tenaga Kerja Terhadap PDRB Jawa Tengah. UNDIP: Skripsi. 
Susilo, Gideon Tri Budi dan Adi, Priyo Hari. 2007. Analisis Kinerja Keuangan Daerah Sebelum dan Sesudah Otonomi. Konferensi Penelitian Akuntansi dan Keuangan Sektor Publik Pertama. Surabaya.

Todaro, Michael P. 2000. Ekonomi Pembangunan, diterjemahkan oleh Haris Munandar. Edisi Kelima. Bumi Aksara : Jakarta.

Undang-Undang Republik Indonesia Nomor 32 Tahun 2004 tentang Pemerintahan Daerah.

Undang-undang Republik Indonesia Nomor 33 Tahun 2004 Tentang Perimbangan Keuangan Antara Pemerintah Pusat dan Pemerintahan Daerah

Wibowo, Sri Muktiono. 2007. Dampak APBD Terhadap Perkembangan Ekonomi Lokal. Konferensi Penelitian Akuntansi dan Keuangan Sektor Publik Pertama. Surabaya.

Worlu, Christian N. 2012. Tax Revenue and Economic Development In Nigeria: A Macroeconomic Approach. Academic Journal Of Interdiciplinary Studies Published by MCSER-CEMAS-Sapienza University Of Rome Vol 1 No.2. E-ISSN 2281-4612. 